Nutrition Research Reviews (2018), 31, 164-178

(C) The Authors 2018. This is an Open Access article, distributed under the terms of the Creative Commons Attribution licence (http:// creativecommons.org/licenses/by/4.0/), which permits unrestricted reuse, distribution, and reproduction in any medium, provided the original work is properly cited.

\title{
Dairy products and bone health: how strong is the scientific evidence?
}

\author{
Ellen G. H. M. van den Heuvel* and Jan M. J. M. Steijns \\ FrieslandCampina, Stationsplein 4, Post Box 1551, Amersfoort 3800 BN, the Netherlands
}

\section{Abstract}

The relevance of dairy produce for the diminishment of osteoporotic risk is still a matter of scientific debate due to the outcome of a few single observational studies. This review will address the most robust point estimate on the role of dairy products, as reported in systematic reviews and meta-analyses on randomised controlled trials in the case of bone mineralisation or prospective studies in the case of fracture risk. Plain dairy products or those fortified with $\mathrm{Ca}$ and/or vitamin $\mathrm{D}$ improve total body bone mineral content (BMC) by $45-50 \mathrm{~g}$ over 1 year when the daily baseline $\mathrm{Ca}$ intake is lower than $750 \mathrm{mg}$ in Caucasians and Chinese girls. In Caucasian and Chinese women, Ca from (fortified) dairy products increases bone mineral density (BMD) by $0.7-1.8 \%$ over 2 years dependent on the site of measurement. Despite the results on BMC, there are currently no studies that have investigated the potential of dairy products to reduce fracture risk in children. In adult Caucasian women, daily intake of $200-250 \mathrm{ml}$ of milk is associated with a reduction in fracture risk of $5 \%$ or higher. In conclusion, the role of dairy products for BMC or BMD has been sufficiently established in Chinese and Caucasian girls and women. In Caucasian women, drinking milk also reduces fracture risk. More research on the role of dairy products within the context of bone health-promoting diets is needed in specific ethnicities, other than Chinese and Caucasians, and in men.

Key words: Dairy products: Bone health diets: Bone mineral density: Fracture risk

\section{Introduction}

Although dairy products provide more bone-beneficial nutrients, such as protein, $\mathrm{Ca}, \mathrm{Mg}, \mathrm{K}, \mathrm{Zn}$ and $\mathrm{P}$ per unit energy than any other typical food found in the adult diet ${ }^{(1)}$, the relevance of dairy products for the prevention of osteoporotic fractures is still a matter of scientific debate as some large prospective studies have suggested that increased milk consumption during adolescence $^{(2)}$ or adult life $e^{(3)}$ may be associated with a higher (future) hip fracture risk in men ${ }^{(2)}$ or women ${ }^{(3)}$. Yet, observational studies are only hypothesis generating and osteoporosis risk is influenced by multiple factors ${ }^{(4,5)}$, including risk of falling $^{(6)}$. There is broad consensus that high bone mineral density (BMD) will increase the likelihood of reduced osteoporosis and fracture risk in later life ${ }^{(7)}$. Therefore randomised controlled trials (RCT) should indicate efficacy of dairy products to promote BMD. Maximising bone mineral mass during childhood and adolescence, and thus achieving the highest possible peak bone mass at the end of the skeleton's maturation process, may contribute to fracture risk reduction during adolescence and possibly in the elderly. Computer simulations of the bone remodelling process predict that the onset of osteoporosis will be delayed by 13 years ${ }^{(8)}$ and the fracture risk during adult life will be reduced by $50 \%{ }^{(9)}$, if peak bone mass is $10 \%$ higher than the mean and sustained over time. In their review, Rizzoli et $a l{ }^{(8)}$ described that more than $60 \%$ of the variance of peak bone mass is genetically determined, and that the remainder may be amenable to (lifestyle) interventions such as adequate dietary intake of $\mathrm{Ca}$, protein and vitamin $\mathrm{D}$, as well as regular weight-bearing physical activity ${ }^{(8)}$.

With respect to dietary $\mathrm{Ca}$ intake, the findings of Esterle et $a{ }^{(10)}$ suggest that ethnic-specific polymorphisms of the vitamin D receptor gene promoter (VDRp) might play a role in the necessity of dairy product-derived Ca for lumbar spine bone mineral content (BMC) and BMD development, as shown during a 4-year follow-up of European peri- and post-menarcheal girls. On the other hand, research with monozygotic twins suggests that the relative importance of environmental factors for bone mass may increase with advancing age ${ }^{(11)}$.

Differences in fat mass, muscle strength, bone microarchitecture and/or physical activity levels play a role in bone mass ${ }^{(5)}$, since bone tissue adapts its internal structure and mass to mechanical demands to ensure maximal strength with minimal bone mass ${ }^{(12)}$. Humans literally walk on their Ca nutrient reserve; given an adequate $\mathrm{Ca}$ intake we have only as much bone as we need for the mechanical loads we currently experience $^{(13)}$. Therefore, when trying to understand the role of dairy products for bone mineralisation and fracture risk during growth and ageing, other factors such as BMI, physical activity, baseline $\mathrm{Ca}$ intake and vitamin $\mathrm{D}$ status should be taken into account.

Given modern food sources, arguments have been put forward that it is difficult to devise a diet that is 'bone healthy'

Abbreviations: 25(OH)D, 25-hydroxyvitamin D; BMC, bone mineral content; BMD, bone mineral density; HR, hazard ratio; RCT, randomised controlled trial; $\mathrm{RR}$, relative risk.

* Corresponding author: Dr Ellen G. H. M. van den Heuvel, email ellen.vandenheuvel@frieslandcampina.com 
without including three servings of dairy products per $d$, as dairy foods are readily available sources of bone-relevant nutrients, and furthermore support skeletal muscle health ${ }^{(6,7,14)}$. Many single studies underscore the beneficial or at least neutral effects of dairy products on bone. Nevertheless, the relevance of dairy produce for the diminishment of osteoporotic risk is still a matter of scientific debate. Systematic reviews and metaanalyses on RCT in the case of bone mineralisation or prospective studies in the case of fracture risk have been published regularly with a growing number of studies; the number of studies analysed differs per analysis, from a few studies only up to fourteen studies. Meta-analyses yield, besides a higher statistical power, a weighted average of available data, and therefore a more robust point estimate. This review will address the most up-to-date literature with the highest strength evidence possible on dairy products and bone health in a life-cycle perspective, with a primary focus on $\mathrm{BMD} / \mathrm{BMC}$ and a reduction of fracture risk by including systematic reviews and meta-analyses. As the available systematic reviews and meta-analyses are heterogeneous in nature, we analysed in addition comparisons between dairy products and Ca supplements or other food products, vitamin D-fortified dairy and unfortified dairy products, as well as effects of different types of dairy products.

\section{Methodology and scope}

This review aims to present the most up-to-date literature with the highest strength evidence, i.e. meta-analyses and systematic reviews ${ }^{(15)}$ related to dairy products and BMC or BMD and fracture risk. The most optimal systematic reviews/metaanalyses included RCT on BMC or BMD and prospective studies on fracture risk. When other designs were included in the systematic review/meta-analyses, the discussion was restricted to RCT for BMD/BMC and prospective studies for fracture risk. The more recent individual RCT on BMD/BMC and prospective study on fracture risk, not yet included in the systematic reviews or meta-analyses, were separately discussed. To this end, we conducted an extensive literature search in Scopus and PubMed for papers published in the English language until January 2016, using combinations of the terms bone* OR fracture* OR BMD OR BMC OR osteoporosis OR osteopenia OR skelet*; dairy OR yoghurt OR yogurt OR milk OR cheese OR custard OR curd OR buttermilk OR kefir OR ("dietary calcium"); human OR humans OR people OR persons OR elderly OR children; AND supplement* OR food* OR ("dietary calcium") OR vitamin* OR mineral* OR enrich* OR fortified OR fortify. Table 1 shows an overview of the preconceived in- and exclusion criteria. Main outcome measures of bone health were fractures for adults and children, BMD for adults, and BMC/BMD for children and adolescents. BMC is a better outcome measure of intake and bone mass in children and less dependent on bone size as opposed to $\mathrm{BMD}^{(16)}$.

Nutritional interventions that alter remodelling produce a temporary phase lag between the normally coupled resorption and formation of the bone-remodelling process. This is also called the bone remodelling transient described by Heaney ${ }^{(17)}$, which is a temporary alteration in the balance between bone formation and bone resorption brought about by any factor that affects bone remodelling (for example, drugs, hormones or nutrients that alter either secretion of parathyroid hormone or its action on bone). According to Heaney ${ }^{(17)}$, the optimal study length is just long enough to get a fix on the post-transient, steady state, which usually is a total duration of two to three remodelling periods, which according to their data begins at about 1.5 years in adults. The remodelling activity is spread out over several months (several weeks in growing children, approximately 3 months in young adults and 6-18 months in older adults $\left.{ }^{(17)}\right)$. Although some think interventions with $\mathrm{Ca}$ or dairy product supplementation in children and adolescents are generally too short (1-3 years) to address the question of whether it is the temporary adaptation of bone tissue to the alteration in $\mathrm{Ca}$ intake that leads to peak bone mass ${ }^{(18)}$, most RCT have been 1-2 years in duration ${ }^{(19)}$. Because of this background and estimated annual losses of bone mass normally seen with ageing are in the range of about $1-2 \%$ per year ${ }^{(19)}$,

Table 1. Overview of preconceived inclusion and exclusion criteria

\begin{tabular}{|c|c|}
\hline \multirow[t]{3}{*}{$\begin{array}{l}\text { Study population } \\
\text { Inclusion }\end{array}$} & Apparently healthy subjects \\
\hline & Children, adolescents, adults, elderly ( $>1$ year) \\
\hline & All races and ethnicities \\
\hline \multirow{2}{*}{ Exclusion } & Unhealthy subjects (for example, chronic diseases) and hospitalised subjects \\
\hline & Preterm and term infants (babies) $(<1$ year) \\
\hline \multirow{6}{*}{$\begin{array}{l}\text { Outcome of bone health } \\
\text { Inclusion (first priority) }\end{array}$} & Inclusion and exclusion criteria depend on topic \\
\hline & All types of fractures \\
\hline & Bone mineral density measured with $\mathrm{DEXA} \geq 2$ years \\
\hline & Bone mineral density measured with $\mathrm{pQCT} \geq 2$ years \\
\hline & Bone mineral content in children/adolescents $\geq 1$ year \\
\hline & Bone mineral density/content $<1$ or 2 years of intervention, when included in systematic reviews and meta-analyses \\
\hline \multirow[t]{2}{*}{$\begin{array}{l}\text { Exclusion or second } \\
\text { priority }\end{array}$} & $\begin{array}{l}\text { Bone mineral density measured in children } \\
\text { Bone health markers }\end{array}$ \\
\hline & Bone mineral density measured $<2$ years (included in some meta-analyses) \\
\hline \multirow{3}{*}{$\begin{array}{l}\text { Exposure/intervention } \\
\text { Inclusion }\end{array}$} & Inclusion and exclusion criteria depend on topic \\
\hline & RCT: plain/unfortified dairy products (milk, yogurt, cheese, buttermilk, custard, curd, kefir) \\
\hline & $\begin{array}{l}\text { Observational: plain/unfortified dairy products (milk, yogurt, cheese, buttermilk, custard, curd, kefir) independent of dietary } \\
\text { assessment method }\end{array}$ \\
\hline
\end{tabular}

DEXA, dual-energy X-ray absorptiometry; $\mathrm{pQCT}$, peripheral quantitative computed tomography; $\mathrm{RCT}$, randomised controlled trial. 
we set a preferred minimal study duration for studies on BMD in adults of 2 years. Because of a shorter remodelling period in children, the preferred minimal study duration for studies on BMC in children was set at 1 year.

In total, six meta-analyses and two systematic reviews, describing thirty-three unique RCT and twenty-five prospective studies, and three individual prospective studies, were discussed that complied with our criteria. The available systematic reviews/meta-analyses are heterogeneous in nature and therefore we provide additional information that enabled us to review the outcome effects when comparing $\mathrm{Ca}$ - and/or vitamin D-fortified dairy products with non-fortified dairy products, Ca supplements or other food products. These studies included also single RCT and/or observational studies.

\section{Dairy products and bone health in children and adolescents}

\section{Dairy products and bone mineral content/bone mineral} density in children and adolescents

As shown in Table 2, our search for relevant papers on dairy products and BMD or BMC in children and adolescents yielded two meta-analyses on RCT and two systematic reviews on RCT and observational studies for discussion. In total, in these four papers, nineteen unique RCT were described of which fourteen showed a beneficial effect of dairy products/milk or Ca from dairy products/milk on BMC in children and four showed no effect.

The earliest meta-analysis of Huncharek et al. ${ }^{(16)}$ comprised twenty-one RCT that measured BMC. In total 2460 subjects were included in a pooled analysis, which showed no effect of dairy products (four studies) or Ca (eight studies) on total body BMC, with baseline Ca intake varying from 417 to $1198 \mathrm{mg} / \mathrm{d}$. Pubertal status, age, study duration and site of BMC measurement varied widely across studies; however, sensitivity analyses suggested that baseline $\mathrm{Ca}$ intake explained most of the observed statistical heterogeneity. Subgroup analysis revealed that (fortified) dairy products significantly increased total body BMC by $50(95 \%$ CI 24, 77) $\mathrm{g}$ in children with low baseline Ca intakes (three RCT; $n$ 1163; 417-746 mg/d). Only two of these studies used normal milk as the intervention $(568 \mathrm{ml} \mathrm{milk} / \mathrm{d})^{(20)}$. The other used milk fortified with $\mathrm{Ca}(245 \mathrm{mg} / \mathrm{d})$ and with or without $3 \cdot 3 \mu \mathrm{g}$ vitamin $\mathrm{D} / \mathrm{d}^{(21)}$ or milk powder with 600 or $1300 \mathrm{mg} \mathrm{Ca} / \mathrm{d}^{(22)}$.

The second meta-analysis ${ }^{(23)}$ showed a comparable increase of 40 (95\% CI 18, 63) g in total body BMC (four RCT; $n$ 1511) due to unfortified or Ca-fortified milk with/without vitamin D in children aged $10-14$ years. Three of the four milk-based studies were not included in Huncharek's meta-analysis ${ }^{(16)}$; one because of a small sample size $\mathrm{s}^{(24)}$ and two Asian studies probably due to Chinese language in the source documents ${ }^{(25,26)}$. The beneficial effect of unfortified milk was in a similar range; however, one of these two studies had an intervention of only 3 months ${ }^{(24)}$

The systematic review of Lanou et al. ${ }^{(27)}$ focuses on children and young adults (1-25 years) and reviews fifty-eight studies; only three RCT ( $n$ 159) studied dairy products in white girls who were aged 11-18 years and whose mean baseline Ca intakes ranged from 725 to $900 \mathrm{mg} / \mathrm{d}$. One of these three RCT $^{(20)}$ was also part of the meta-analysis by Huncharek et $a l .{ }^{(16)}$, whereas the other two studies were not included in that review due to too low total study sample size (Matkovic et al. ${ }^{(28)}, n$ 31; Chan et al. ${ }^{(29)}, n$ 48). Therefore, this review is not further discussed.

Recently Dror \& Allen $^{(30)}$ included in their systematic review six observational studies and seven RCT (duration 10-24 months; $n$ 992) with healthy and well-nourished children or adolescents aged 2-19 years, using milk powder, Ca extracted from milk, or dairy products as the exposure and total-body or regional BMC as outcomes of interest ${ }^{(30)}$. The largest trial conducted in $\mathrm{Asia}^{(21)}$ was missing from this systematic review. We only will discuss the RCT. Five of the seven RCT were conducted in white female subjects. Baseline Ca intakes ranged from 417 to $900 \mathrm{mg} / \mathrm{d}$. The treatments in the seven RCT did not contain vitamin D although one small $\mathrm{RCT}^{(29)}$, conducted in the USA where mandatory fortification of milk with vitamin $\mathrm{D}$ is applied, might be an exception. Two studies investigated milk Ca ${ }^{(31,32)}$. These three studies and the study of Merrilees et $a l .{ }^{(33)}$ on dairy products were not included in the meta-analysis of Huncharek et al. ${ }^{(16)}$. In all seven RCT there was a significant improvement in BMC due to higher dairy $\mathrm{Ca}$ intakes in at least one population subset at one or more bone sites; in three of the six RCT that measured total body BMC, and in four of the five RCT that measured BMC at the hip sites (for example, femoral neck, trochanter, hip, pelvic). Results at a particular site of measurement were inconsistent ${ }^{(30)}$.

In summary, as shown in Table 2, most studies were conducted in white female children and adolescents, and especially the larger studies were conducted in Chinese subjects with low basal Ca intake levels. These latter studies were included in the meta-analysis of Ma et al. ${ }^{(23)}$. The largest sample size was included in the meta-analysis of Huncharek et al. ${ }^{(16)}$. Both meta-analyses underscore that plain dairy products or fortified with $\mathrm{Ca}$ and/or vitamin $\mathrm{D}$ improve total-body BMC when the daily baseline Ca intake is lower than $750 \mathrm{mg}$. The systematic review of Dror \& Allen $^{(30)}$ confirmed this for $50 \%$ of their selected RCT on total-body BMC. The role of dairy products is less clear for the regional sites of BMC.

\section{Dairy products and fracture risk in children and adolescents}

With regard to the relevance of dairy products in reducing fracture risk in childhood, only observational data of lower scientific strength are available. Two systematic reviews $(27,34)$ were not analysed in detail as these reviews contained mostly case-control studies (see Table 2). However, one prospective study was not discussed in these systematic reviews. This cohort study with 22 years of follow-up in more than 96000 white postmenopausal women and men aged 50 years and older suggested that high consumption of milk during adolescence may adversely influence future fracture risk by increasing height for at least 22 years $^{(2)}$. Frequency of consumption of milk during teenage years and attained height during ages 13 to 18 years were reported at baseline, which was by surprise at an age over 40 years. Among those who consumed 
Table 2. Meta-analyses (MA) and systematic reviews (SR) on dairy products and bone mineral content (BMC) or fracture risk in children and adolescents

\begin{tabular}{|c|c|c|c|c|c|c|c|}
\hline Reference & Number of studies & $n(\%$ male $)$ & Age range & $\begin{array}{l}\text { Different ethnicities } \\
\text { included, besides } \\
\text { Caucasian? }\end{array}$ & $\begin{array}{l}\text { Treatment (duration) in RCT/ } \\
\text { determinant in } \mathrm{OB}\end{array}$ & Results and conclusions & Strengths/limitations ${ }^{*}$ \\
\hline \multicolumn{8}{|l|}{ BMC } \\
\hline $\begin{array}{l}\text { Huncharek } \\
\text { et al. }(2008)^{(16)} \\
\text { MA; SR }\end{array}$ & $\begin{array}{l}\text { MA on } 21 \mathrm{RCT} \text { : } \\
3 \mathrm{RCT} \text { on vitD; } \\
5 \text { on Ca-fortified/plain dairy } \\
\quad \text { products; } \\
2 \text { on milk } \mathrm{Ca} \text {; } \\
8 \text { on } \mathrm{Ca} ; \\
3 \text { on } \mathrm{Ca} / \mathrm{milk} \text { with vitD } \\
\text { SR on } 8 \text { cross-sectional and } \\
\quad 3 \text { prospective studies }\end{array}$ & $\begin{array}{l}\text { RCT: } 3821 \text { (17) } \\
5 / 8 \text { cross-sectional } \\
\text { and } 0 / 3 \\
\text { prospective } \\
\text { included both } \\
\text { sexes }\end{array}$ & $\begin{array}{l}\text { RCT: average } \\
\text { 4-17 years } \\
\text { OB: average } \\
5-20 \text { years }\end{array}$ & $\begin{array}{l}\text { Yes ( } 5 \text { RCT and } 4 \mathrm{OB} \\
\text { in Chinese } \\
\text { subjects) }\end{array}$ & $\begin{array}{l}\text { RCT: dairy products, milk, Ca } \\
\text { with or without vitD, vitD } \\
\text { alone (12-48 months) } \\
\text { OB: dietary Ca or dairy } \\
\text { products }\end{array}$ & $\begin{array}{l}\text { Pooling } 12 \mathrm{RCT} \text { ( } n \text { 2460, } 43 \% \text { Asian) on Ca/ } \\
\text { Ca-fortified or plain dairy products: TB-BMC } \\
2.05 \text { ( } 95 \% \mathrm{Cl}-3.26,7.36) \mathrm{g} \text {. } \\
\text { Pooling } 3 \mathrm{RCT}(n 1163,93 \% \text { Asian) on } \\
\text { Ca-fortifed/plain dairy products with low } \\
\text { baseline dietary } \mathrm{Ca}(417-746 \mathrm{mg} / \mathrm{d}): \\
\text { TB-BMC } 49.9(95 \% \mathrm{Cl} 24.0,76 \cdot 6) \mathrm{g} \text {. } \\
\text { Pooling } 2 \mathrm{RCT}(\mathrm{n} 838,90 \% \mathrm{Asian}) \text { on } \mathrm{Ca} / \text { dairy } \\
\text { products + vitD: TB-BMC } 35(95 \% \mathrm{Cl}-6.8 \text {, } \\
41.8) \mathrm{g} \text {. } \\
\text { Ca-fortified/plain dairy products promote TB- } \\
\text { BMC when baseline Ca intake is low. } \\
\text { No MA of OB was possible, which the authors } \\
\text { found little to add to the results obtained } \\
\text { from the RCT }\end{array}$ & $\begin{array}{l}\text { Studies reporting only BMD were } \\
\text { excluded. Duration of intervention all } \\
\text { RCT } \geq 12 \text { months. } \\
\text { O RCT included in MA with } n / \text { group }<40 \\
\text { Baseline Ca intake was taken into } \\
\text { account; explained large part of } \\
\text { heterogeneity. Only first meta-analysis } \\
\text { on } 12 \text { RCT showed considerable } \\
\text { heterogeneity }(Q=20.46 ; P=0.04) \text {. } \\
\text { Authors noted 'Publication bias was not } \\
\text { statistically examined, but may occur } \\
\text { because published studies are not } \\
\text { representative of all studies ever done' }\end{array}$ \\
\hline $\begin{array}{l}\text { Ma et al. } \\
(2013)^{(23)} \\
\text { MA }\end{array}$ & $\begin{array}{l}4 \text { RCT on TB-BMC } \\
6 \text { RCT TB-BMD }\end{array}$ & $\begin{array}{l}1511(2) \\
2091(1)\end{array}$ & $10-14$ years & $\begin{array}{l}\text { Yes ( } 3 \text { and } 4 \text { on BMC } \\
\text { and BMD, } \\
\text { respectively, } \\
\text { in Asian) }\end{array}$ & $\begin{array}{l}\text { Milk or milk fortified with } \\
\text { Ca with or without vitD }\end{array}$ & 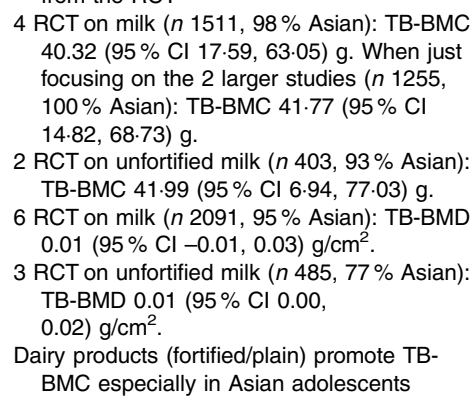 & $\begin{array}{l}\text { BMC and BMD separately analysed. } \\
\text { Duration of intervention of } 1 / 4 \text { RCT on } \\
\text { BMC }<12 \text { months; } 1 / 6 \text { RCT on } \\
\text { BMD }<12 \text { momths. } \\
\text { n/group in } 1 / 4 \mathrm{RCT} \text { on } \mathrm{BMC}<40 \text {; in } 2 / 6 \\
\text { RCT on } \mathrm{BMD}<40 \text {. } \\
\text { No significant heterogeneity, based on } x^{2} \\
\text { distribution. No strong evidence of } \\
\text { publication bias, based on the funnel } \\
\text { plot }\end{array}$ \\
\hline $\begin{array}{l}\text { Lanou et al. } \\
(2005)^{(27)} \\
\text { SR }\end{array}$ & $\begin{array}{l}12 \text { RCT on bone mass } \\
\text { ( } 3 \text { on dairy products) } \\
\text { OB on BMC/BMD not } \\
\text { reviewed }\end{array}$ & $\begin{array}{l}\text { RCT on dairy } \\
\quad \text { products } n 159(0)\end{array}$ & $\begin{array}{l}\text { Search was limited } \\
\text { to }<25 \text { years } \\
\text { (excluding } \\
\text { infants) }\end{array}$ & No & $\begin{array}{l}\text { Total dietary Ca or dairy } \\
\text { product intake }\end{array}$ & $\begin{array}{l}\text { 2/3 RCT showed a positive effect of dairy } \\
\text { products on TB-BMC/BMD and of some } \\
\text { regional sites }\end{array}$ & $\begin{array}{l}\text { Duration of intervention all } \\
R C T>12 \text { months. } \\
2 / 3 \text { RCT included in MA with } n / \text { group }<40\end{array}$ \\
\hline $\begin{array}{l}\text { Dror \& Allen } \\
(2014)^{(30)} \\
\text { SR }\end{array}$ & 7 RCT; 6 OB (not reviewed) & 992 (5/7 RCT 0\%) & RCT: $7.9-15$ years & $\begin{array}{r}\text { Yes (1 RCT with } \\
344 \text { Chinese) }\end{array}$ & $\begin{array}{l}\text { Milk or dairy product intake or } \\
\text { milk-extracted } \mathrm{Ca} \\
\text { (10-24 months) }\end{array}$ & $\begin{array}{l}\text { In } 3 / 6 \text { RCT that measured total-body BMC, } \\
\text { and in } 4 / 5 \text { RCT that measured BMC at the } \\
\text { hip sites (for example, femoral neck, } \\
\text { trochanter, hip, pelvic), a significant } \\
\text { improvement in BMC was found }\end{array}$ & $\begin{array}{l}\text { Studies reporting only BMD were } \\
\text { excluded. } \\
\text { Duration of intervention } 2 / 7 \mathrm{RCT} \\
<12 \text { months. } \\
4 / 7 \mathrm{RCT} \text { included in MA with } n / \text { group }<40\end{array}$ \\
\hline \multicolumn{8}{|l|}{ Fracture risk } \\
\hline $\begin{array}{l}\text { Händel et al. } \\
(2015)^{(34)} \\
\text { SR }\end{array}$ & $\begin{array}{l}6 \text { case-control on dairy } \\
\text { products and (recurrent) } \\
\text { fracture risk }\end{array}$ & $\begin{array}{l}556 \text { cases }(69) \text { and } \\
\geq 556 \text { controls }(63)\end{array}$ & $2-13$ years & $\begin{array}{l}1 / 6 \text { case-control } \\
\text { studies in African } \\
\text { Americans }\end{array}$ & $\begin{array}{l}\text { Milk avoidance/milk or dairy } \\
\text { product intake }\end{array}$ & $\begin{array}{l}\text { 3/6 case-controlled studies showed an } \\
\text { association between low Ca intake via milk } \\
\text { ( } 1 \text { even looked at milk avoidance); } 1 \\
\text { showed an association between high Ca } \\
\text { intake via cheese; } 3 \text { showed no association } \\
\text { between } \mathrm{Ca} \text { intake and fracture risk }\end{array}$ & Low-strength studies included \\
\hline $\begin{array}{l}\text { Lanou et al. } \\
(2005)^{(27)} \\
\text { SR }\end{array}$ & $\begin{array}{l}\text { On fracture risk: } 2 / 3 \\
\text { retrospective/case-control } \\
\text { on dairy products); } 0 / 1 \\
\text { prospective on dairy } \\
\text { products; } 0 / 4 \text { cross- } \\
\text { sectional on dairy products }\end{array}$ & No & $\begin{array}{l}\text { Search was limited } \\
\text { to }<25 \text { years } \\
\text { (excluding } \\
\text { infants) }\end{array}$ & $\begin{array}{l}\text { Not in studies on } \\
\text { dairy products }\end{array}$ & $\begin{array}{l}\text { Total dietary } \mathrm{Ca} \text { (not reviewed) } \\
\text { or dairy product intake }\end{array}$ & $\begin{array}{l}1 \text { case-control study } y^{(93)} \text { and } 1 \text { retrospective } \\
\text { study }{ }^{\left({ }^{94)}\right.} \text { did not show an association } \\
\text { between a higher dairy product intake and } \\
\text { fracture risk reduction, although the latter } \\
\text { found that high total Ca intake was } \\
\text { associated with reduced fracture incidence } \\
\text { in Caucasian girls and boys }\end{array}$ & $\begin{array}{l}\text { Conclusion based on a few low-strength } \\
\text { studies }\end{array}$ \\
\hline
\end{tabular}

RCT, randomised controlled trial; OB, observational study; vitD, vitamin D; TB, total body; BMD, bone mineral density.

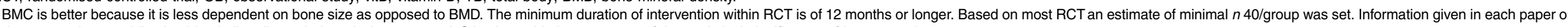
heterogeneity or publication bias is literally copied, and when reported $Q$ is given, this is a measure of the statistical significance of heterogeneity. 
at least four glasses of milk per $\mathrm{d}$, men were on average $1.9 \mathrm{~cm}$ taller and women were $1.7 \mathrm{~cm}$ taller than those who consumed fewer than two glasses per week during teenage years. Each additional glass of milk per $d$ during teenage years was associated with a significant $9 \%$ higher risk of hip fracture in men, but not in women. The positive association observed in men was partially mediated through attained height, as was expected by the authors because of presumed vulnerability to bone fracture due to increased height associated with milk exposure. Unlike milk, cheese consumption during teenage years was not associated with hip fractures in men or women; neither was it associated with attained height. Because of method limitations (for example, not including many important confounders or including too many like current $\mathrm{Ca}$ intake) in their study design and data analysis, the conclusions of Feskanich et $a l .{ }^{(2)}$ were not considered valid by Howland ${ }^{(35)}$, Weaver $^{(36)}$ or Heaney ${ }^{(37)}$. In their reply Feskanich \& Willett ${ }^{(38)}$ stated that other confounders were not of importance because they were not associated with the determinant/outcome and that excluding the current $\mathrm{Ca}$ intake did not change their outcome. Besides the arguments forwarded in these three publications, another shortcoming is the one-time assessment of dairy product intake during teenage years, assessed at a later age by a short twenty-three-item FFQ. A one-time assessment of dairy product intake does not predict intake over very long follow-ups, as was shown in the Amsterdam Growth and Health Study in which Ca and dairy product intake was studied six times over 15 years from age 13 to 27 years. The predictability of $\mathrm{Ca}$ intake over time was not sufficiently strong to identify teenagers who are likely to maintain an inadequate $\mathrm{Ca}$ intake in adulthood $^{(39)}$. Therefore, predicting fracture risk based on adolescence dietary behaviour seems rather difficult, if not impossible.

\section{Conclusions on dairy products and bone health for children} and adolescents

In conclusion, especially based on two meta-analyses ${ }^{(16,23)}$, plain dairy products or fortified with $\mathrm{Ca}$ and/or vitamin $\mathrm{D}$ improve total-body BMC of Chinese and Caucasian girls by 45-50 g over 1 year when the daily baseline Ca intake is lower than $750 \mathrm{mg}$. This is comparable with the higher total BMC of $117 \mathrm{~g}$ over 2 years surrounding the peak in bone accretion found in boys and girls, when being physically active ${ }^{(40)}$. No conclusion can be drawn on the regional sites of BMC. Substitution of a deficiency appears more effective than augmentation above a normal intake.

With regard to childhood fracture risk, no conclusion can be drawn based on the two systematic reviews because of the low strength of scientific evidence of the described studies. Further study is also needed on the association between multiple assessments of dairy product intake during childhood for future fracture risk in adult life, although the necessary very long follow-up of at least 20-30 years makes this almost impossible to execute. Also, an enormous number of subjects would need to be included to be able to face the drop-outs and still have enough power to see differences in fracture risk after a followup of more than 20 years.

\section{Dairy products and bone health in adults}

\section{Dairy products and bone mineral density in adults}

One systematic review and one meta-analysis on RCT were found with regard to the relevance of dairy products for BMD in adults (see Table 3). The systematic review of Weinsier \& Krumdieck $^{(41)}$ reported seven RCT, along with a number of cross-sectional and case-control studies. Of these RCT, four were conducted in children and adolescents and only three in adult or postmenopausal women (two included in the meta-analysis mentioned below and one prospective study erroneously classified as RCT). Therefore, we will not include the outcome of this review in our conclusion on adult bone health.

Recently, a random-effects meta-analysis of fifteen RCT was performed to determine whether increasing $\mathrm{Ca}$ intake from dietary sources affects BMD, of which three were on hydroxyapatite $^{(42)}$. We restrict to the seven RCT that intervened for a duration of 2 years; i.e. six RCT on dairy products $(n$ 805) and one on hydroxyapatite ( $n$ 60). Between 800 and $1200 \mathrm{mg}$ of $\mathrm{Ca}$ by dairy products and $3320 \mathrm{mg}$ Ca by hydroxyapatite were supplied per d. One RCT included male participants, and one of the seven RCT supplied $20 \mu \mathrm{g}$ vitamin D/d. Based on the title of the paper, about $46 \%$ of the total numbers of participants included in the seven RCT on dietary Ca were part of the Chinese population $(n$ 400). More details are given in Table 3. The meta-analysis showed that a higher $\mathrm{Ca}$ intake from dietary sources increased BMD by $0 \cdot 7-1 \cdot 8 \%$ at the lumbar spine, total body, total hip and femoral neck after 2 years. The number of subjects per site of BMD measurement was between 358 and 816 , and $P$ values were 0.001 or lower. A beneficial effect on BMD of the forearm could not be demonstrated $(0.1 \% ; P=0.65$; $n$ 171). The authors mentioned that there is a possibility of publication bias due to the presence of more small- to moderate-sized highly positive studies, indicating that larger studies are needed. When excluding the trials on hydroxyapatite, the authors mentioned there was little change in the results.

A subgroup analysis showed no significant difference in change in lumbar spine BMD when baseline dietary Ca intake was above or below $800 \mathrm{mg} / \mathrm{d}(P=0.54$; four and five RCT, respectively). Unfortunately, this analysis was only feasible for the lumbar spine measurements, comparing different studies, at 1 year of intervention.

Based on one meta-analysis, a 2-year intervention with a higher $\mathrm{Ca}$ intake, mainly from dairy products, increased BMD of the lumbar spine, total body, total hip and femoral neck by $0 \cdot 7-1 \cdot 8 \%$ in participants aged 50 years or older at baseline.

\section{Dairy products and fracture risk in adults}

The role of dairy products with respect to fracture risk was investigated in three meta-analyses, which included in total fourteen unique prospective studies. Of these, twelve prospectively found a beneficial association between the intake of milk, dairy protein, a dietary pattern including dairy products, or dietary $\mathrm{Ca}$, and fracture risk at one or more sites. Besides the meta-analyses we reviewed one systematic review of 
Table 3. Meta-analyses (MA) or systematic reviews (SR) on the effect of dairy products on bone mineral density (BMD) or fracture risk in adults

\begin{tabular}{|c|c|c|c|c|c|c|c|}
\hline Reference & Number of studies & $n$ (\% male) & Age range & $\begin{array}{l}\text { Different ethnicities } \\
\text { included, besides } \\
\text { Caucasian? }\end{array}$ & $\begin{array}{l}\text { Treatment (duration of } \\
\text { intervention in RCT)/ } \\
\text { determinant in } \mathrm{OB}\end{array}$ & Results and conclusions & Strengths/limitations ${ }^{*}$ \\
\hline \multicolumn{8}{|l|}{ BMD } \\
\hline $\begin{array}{l}\text { Weinsier \& } \\
\text { Krumdieck } \\
(2000)^{(41)} \\
\text { SR }\end{array}$ & $\begin{array}{l}7 \text { RCT on bone mass; } \\
5 \text { prospective ( } 0 \text { on bone mass); } \\
11 \text { case-control ( } 4 \text { on bone } \\
\text { mass); } 23 \text { cross-sectional ( } 20 \\
\text { on bone mass) }\end{array}$ & $\begin{array}{l}5 / 7 \mathrm{RCT} \text {, only } \\
\text { females }\end{array}$ & $\begin{array}{l}\text { 7-103 years } \\
\text { (4/7 RCT in } \\
\text { children aged } \\
7-17 \text { years) }\end{array}$ & Yes (in 8 included OB) & $\begin{array}{l}\text { Dairy product } \\
\text { consumption } \\
\text { (3.5-36 months)/dairy } \\
\text { product consumption }\end{array}$ & $\begin{array}{l}\text { Of the } 7 \mathrm{RCT}, 5 \text { were classified as showing } \\
\text { favourable effects. } \\
\text { Of } 57 \text { outcomes (bone mass, fractures, Ca } \\
\text { balance) of the effects of dairy foods on bone } \\
\text { health, } 53 \% \text { were NS, } 42 \% \text { were favourable, } \\
\text { and } 5 \% \text { were unfavourable. Of } 21 \text { stronger } \\
\text { evidence studies, } 57 \% \text { were NS, } 29 \% \text { were } \\
\text { favourable, and } 14 \% \text { were unfavourable. The } \\
\text { overall ratio of favourable to unfavourable } \\
\text { effects in the stronger studies was } 2.0 \text { ( } 4.0 \\
\text { in }<30 \text {-year-olds, } 1.0 \text { in } 30-50 \text {-year-olds, and } \\
1.0 \text { in }>50 \text {-year-olds) }\end{array}$ & $\begin{array}{l}\text { Main limitation is that only } 3 \text { RCT were conducted } \\
\text { in adults; therefore, this study is not taken into } \\
\text { account in the conclusion of this review. } \\
\text { Duration of intervention of } 3 / 7 \text { RCT }<24 \text { months. } \\
4 / 7 \text { RCT with } n / \text { group }<40\end{array}$ \\
\hline $\begin{array}{l}\text { Tai et al. } \\
(2015)^{(42)} \\
\text { MA }\end{array}$ & $\begin{array}{l}15 \text { RCT: } \\
8 \text { on dairy products ( } 3 \text { with vitD); } \\
4 \text { on dairy products and } \mathrm{Ca} ; \\
3 \text { on non-dairy products }(1 \text { with } \\
\text { vitD and } 2 \text { including } \mathrm{Ca} \text { ) }\end{array}$ & $\begin{array}{l}1996(18) \\
\text { RCT with a } \\
\quad \text { treatment } \\
\text { duration } \geq 2 \\
\text { years: } n 865 \\
\text { (21) }\end{array}$ & $52-72$ years & $\begin{array}{l}\text { Not stated, although } \\
\text { at least } 3 \text { of the } \\
\text { RCT described in } \\
\text { their title to be } \\
\text { conducted in a } \\
\text { Chinese } \\
\text { population } \\
\text { (n } 541) \text {. } \\
\text { RCT with } \\
\text { intervention } \\
\geq 2 \text { years: } 46 \%\end{array}$ & $\begin{array}{l}\text { Ca from diet. Ca from } \\
\text { supplements is not } \\
\text { reviewed by us }\end{array}$ & $\begin{array}{l}\text { Increasing Ca intake from dietary sources } \\
\text { increased BMD by } 0.7-1.8 \% \text { at total hip, TB, } \\
\text { LS and FN at } 2 \text { years }(P \leq 0.001) \text {. There was } \\
\text { no effect on BMD at the forearm (0.1\%; } \\
P=0.65 ; n 171) \text {. When restricted the analyses } \\
\text { to the } 12 \mathrm{RCT} \text { of milk or dairy products, by } \\
\text { excluding } 3 \text { trials of hydroxyapatite, there was } \\
\text { little change in the results (data not shown). } \\
\text { Subgroup analyses including baseline Ca } \\
\text { intake, Ca dose, vitD intake, risk of bias, or } \\
\text { age did not affect the outcome }\end{array}$ & $\begin{array}{l}\text { Duration of intervention of } 8 / 15 \\
\text { RCT }<24 \text { months, of which } 2 / 3 \text { on } \\
\text { hydroxyapatite. } \\
6 / 15 \text { RCT with } n / \text { group }<40 \text {, of which } 2 \text { on } \\
\text { hydroxyapatite. } \\
\text { In the } \geq 2 \text {-year analyses, } P \text { ranged from } 0 \% \text { (NS) } \\
\text { for TB and LS, to } 43 \text { and } 72 \% \text { for } F N \text { and total } \\
\text { hip, respectively }(P<0.05 \text { ). Therefore, authors } \\
\text { used random-effects meta-analyses that take } \\
\text { high } P \text { into account, which was 'often due to } \\
\text { the presence of a small number of outlying } \\
\text { results'. } \\
\text { Egger's regression model and visual inspection } \\
\text { of funnel plots showed a symmetry caused by } \\
\text { more small- to moderate-sized highly positive } \\
\text { studies, 'raising the possibility of publication } \\
\text { bias' }\end{array}$ \\
\hline \multicolumn{8}{|l|}{ Fracture risk } \\
\hline $\begin{array}{l}\text { Xu et al. } \\
(2004)^{(43)} \\
\text { MA }\end{array}$ & $\begin{array}{l}4 \text { prospective with mean FU of } \\
5 \cdot 2-14 \cdot 6 \text { years } \\
2 \text { nested case-control, and } 4 \\
\text { case-control }\end{array}$ & $39780(0)$ & $>35$ years & No & $\begin{array}{l}\text { Dietary Ca intake from at } \\
\text { least } 3 \text { types of food; } \\
\text { studies included data } \\
\text { from countries where } \\
\text { mandatory fortification } \\
\text { of milk with vitD is } \\
\text { applied }\end{array}$ & $\begin{array}{l}\text { Based on prospective study designs: Pooled RR } \\
\text { ( } n 33673 \text { ) for hip fracture is } 0.96 \\
(95 \% \mathrm{Cl} 0.89,1.04) \text {. } \\
\text { Only a MA could be done on hip fractures as not } \\
\text { enough studies were available for forearm or } \\
\text { vertebral fractures. No association between } \\
\text { dietary Ca and hip fractures in women for each } \\
\text { of the } 3 \text { study designs was found }\end{array}$ & $\begin{array}{l}\text { No details on dietary Ca sources was given, } \\
\text { although } 73 \% \text { of the subjects originated from } \\
\text { prospective studies aimed to study the role of } \\
\text { dairy products in fracture risk. } \\
\text { No significant heterogeneity, as assessed by a } \\
\text { general variance-based method. Including all } \\
\text { cohort studies (not mentioned per study design), } \\
\text { the funnel plot showed no evidence of } \\
\text { publication bias (Egger's test) }\end{array}$ \\
\hline $\begin{array}{l}\text { Kanis et al. } \\
(2005)^{(45)} \\
\text { MA }\end{array}$ & $\begin{array}{l}6 \text { prospective (Europe, Australia } \\
\text { and Canada), with FU of 3-8 } \\
\text { years }\end{array}$ & $39563(31)$ & $21-103$ years & No & $\begin{array}{l}\text { Ca intake, estimated } \\
\text { from the intake of milk } \\
\text { (but not cheese, } \\
\text { yoghurt or } \\
\text { supplements); studies } \\
\text { included data from } \\
\text { countries where } \\
\text { mandatory fortification } \\
\text { of milk with vitD is } \\
\text { applied }\end{array}$ & $\begin{array}{l}\text { A low intake of } \mathrm{Ca} \text { (less than } 1 \text { glass of milk daily) } \\
\text { was not associated with a significantly } \\
\text { increased risk of any fracture, osteoporotic } \\
\text { fracture or hip fracture. There was no } \\
\text { difference in risk ratio between men and } \\
\text { women. When both sexes were combined } \\
\text { there was a small but NS increase in the risk of } \\
\text { osteoporotic (RR } 1.10 ; 95 \% \mathrm{Cl} 1.00,1.21 ; \\
P=0.056 \text { ) and of hip fracture (RR } 1.17,95 \% \\
\mathrm{Cl} 0.91,1.50 ; \mathrm{NS} \text { ) with a low milk Ca intake. } \\
\text { There was also a small increase in the risk of } \\
\text { an osteoporotic fracture with age which was } \\
\text { significant at the age of } 80 \text { years (RR } 1.15 ; \\
95 \% \mathrm{Cl} 1.02,1.30 \text { ) and above. The } \\
\text { association was no longer significant after } \\
\text { adjustment for BMD. No significant relationship } \\
\text { was observed by age for low milk intake and } \\
\text { hip fracture risk }\end{array}$ & $\begin{array}{l}\text { Individual patient analysis was performed, which } \\
\text { has the advantage that original research data } \\
\text { for each participant in each study were } \\
\text { included, making re-analysis of the data in a } \\
\text { consistent way possible. } \\
\text { Covariates included were current time, current } \\
\text { age, milk intake and milk intake } \times \text { current age. } \\
\text { No significant heterogeneity between cohorts } \\
\text { was found }(P>0.3 ; P=13(95 \% \mathrm{Cl} 0,54) \% \\
\text { for osteoporotic fracture and } P=0(95 \% \mathrm{Cl} \text {, } \\
25) \% \text { for hip fracture), and a fixed-effects } \\
\text { model was used }\end{array}$ \\
\hline
\end{tabular}




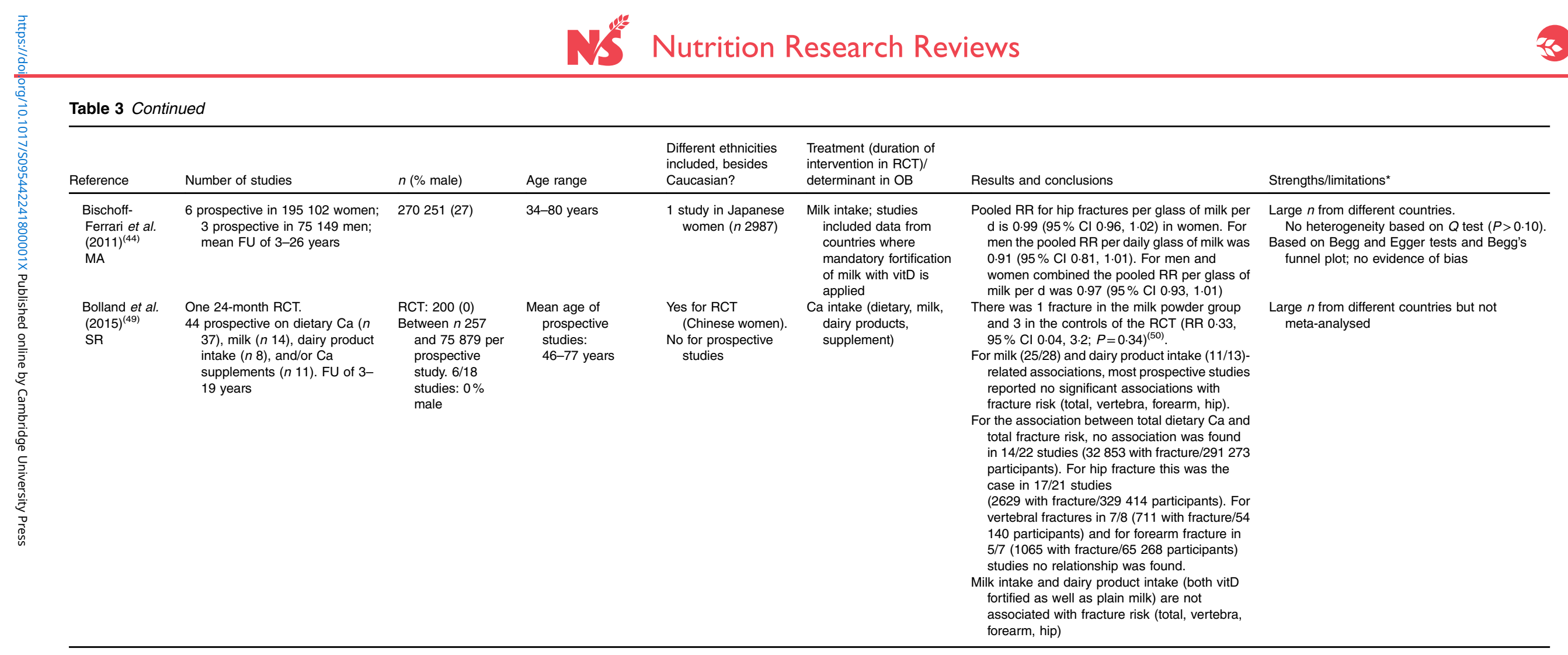

$\mathrm{RCT}$, randomised controlled trial; OB, observational study; vitD, vitamin D; TB, total body; LS, lumbar spine; FN, femoral neck; FU, follow-up period; RR, relative risk.

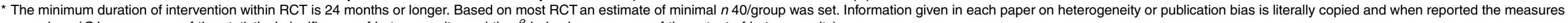
are given ( $Q$ is a measure of the statistical significance of heterogeneity, and the ${ }^{2}$ index is a measure of the extent of heterogeneity). 
prospective studies, and two recent prospective studies, not included in the previous analyses (see Table 3).

$\mathrm{Xu}$ et $a l .{ }^{(43)}$ included in their meta-analysis three study designs to determine whether a low dietary $\mathrm{Ca}$ intake from different types of foods is one of the risk factors for hip, forearm or vertebral fractures in women aged $>35$ years. They selected four prospective studies ( $n 39780$ residents from USA and Europe) with a mean follow-up period between 5.2 and 14.6 years. Only one meta-analysis could be done: no significant association was found between dietary $\mathrm{Ca}$ intake and hip fractures (relative risk (RR) 0.96; $95 \%$ CI 0.89, 1.04). The limitation of this meta-analysis is that no details on dietary $\mathrm{Ca}$ sources were provided, although $73 \%$ of the subjects originated from prospective studies aimed to study the role of dairy products in fracture risk. Although included in the meta-analysis of Bischoff-Ferrari et al. ${ }^{(44)}$, the second meta-analysis of Kanis et $a l^{(45)}$ is unique in pooling individual data from 39563 adults and elderly from six prospective studies carried out in Europe, Australia and Canada. These data were not included in the meta-analysis of $\mathrm{Xu}$ et $a l .{ }^{(43)}$. This meta-analysis of individual patient data assessed whether low Ca intake, estimated from the intake of milk (but not cheese, yoghurt or supplements), could be used to serve as an additional risk factor for case finding of osteoporotic patients. The incidence of any, osteoporotic or hip fracture over 3-8 years was 3191, 2469 and 413, respectively. When adjusted for BMD, which could be considered to be an effect modifier and therefore as expected, a low intake of milk was not associated with fracture risk (any, hip or osteoporotic) for the various age categories analysed above 50 years of age. There was no difference in risk ratio between men and women. When not adjusted for BMD, the risk ratio for having an osteoporotic fracture with low milk intake was borderline significant (RR 1.10; $95 \%$ CI 1.00, 1.21; $P=0.056$ ). When RR was examined by age in men and women combined, drinking less than one glass of milk per $d$ was associated with an increased risk of osteoporotic fracture only from the age of 80 years (RR $1 \cdot 15 ; 95 \%$ CI 1.02, 1.30). This was not the case for hip fracture or any fracture ${ }^{(45)}$.

The third meta-analysis of Bischoff-Ferrari et al. ${ }^{(44)}$ focused solely on hip fractures in middle-aged or older men and women, and included the data from Kanis et al. ${ }^{(45)}$. Compared with the meta-analysis of Xu et al. ${ }^{(43)}$, Bischoff-Ferrari et al. ${ }^{(44)}$ included only studies that gave information on milk intake; therefore there is only overlap of two studies ${ }^{(46,47)}$. BischoffFerrari et $a l .{ }^{(44)}$ did not find an association between milk intake and hip fracture risk in women (195 102 women, 3574 hip fractures, pooled RR per glass of milk (approximately $300 \mathrm{mg}$ of Ca) per $\mathrm{d}=0.99 ; 95 \%$ CI $0.96,1.02$ ). The authors mentioned that the results among women were somewhat dominated by the study of Michaëlsson et al. ${ }^{(48)}$ with 60689 participants, although the test for heterogeneity did not reach significance when including all studies. Excluding the study of Michaëlsson et $a l .{ }^{(48)}$, there was a marginally significant $5 \%$ reduction of hip fracture risk per glass of milk intake per d (pooled RR 0.95, $95 \%$ CI $0.90,1.00 ; P=0.049)$. Moreover, the proportion of total variation in study estimates, due to heterogeneity, was $25 \%$ lower when excluding the Swedish study by Michaëlsson et $a{ }^{\left({ }^{(44)}\right.}$. More data are needed in men (75 149 men, 195 hip fractures) for whom the pooled RR per daily glass of milk was 0.91 (95\% CI 0.81, 1.01), suggesting a borderline significant benefit in men. When cohorts of both women and men were analysed jointly, there was a weak and non-significant inverse association between milk intake and hip fracture risk (pooled RR per glass of milk per $d=0.97,95 \%$ CI $0.93,1 \cdot 01$ ). All three meta-analyses included data from countries where mandatory fortification of milk with vitamin D is applied.

Bolland et al. ${ }^{(49)}$ recently published a systematic review of randomised controlled and prospective cohort studies on $\mathrm{Ca}$ intake with fracture as an endpoint. Regarding Ca from dairy products or milk, they found one RCT with milk powder ${ }^{(50)}$ ( $n$ 200; one fracture in the milk group and three in the controls in 2 years' time; $P=0.34$ ), and eighteen prospective studies with sample sizes varying between 257 and 75879 subjects. Six of the eighteen included cohort studies consisting of $100 \%$ women. For nearly all eighteen included prospective studies on milk and/or dairy product intake (both vitamin D-fortified and -unfortified milk) there was no association with fracture risk (total, vertebra, forearm, hip), with twenty-five of twenty-eight neutral associations for milk and eleven of thirteen for dairy product intake ${ }^{(49)}$. As compared with the two other metaanalyses, a larger number of studies were included in the systematic review of Bolland et al. ${ }^{(49)}$ because of a different aim (for example, milk $v$. Ca intake, or type of fracture); the prospective study of Munger et al. ${ }^{(51)}$ was probably excluded from the meta-analysis because it focused on protein intake. Bolland et al. ${ }^{(49)}$ concluded that dietary Ca intake is not associated with risk of fracture, and that there is currently no evidence that increasing dietary Ca intake to at least $1000-1200 \mathrm{mg} / \mathrm{d}$ prevents fractures. The limitation of this systematic review is that there was no meta-analysis performed to obtain a pooled and weighted average from the results of the individual studies on dietary or dairy $\mathrm{Ca}$.

Finally, we discuss two large prospective studies that were not included in the described papers before. Since milk products in Australia and Sweden are not mandatorily fortified with vitamin $\mathrm{D}$, and vitamin $\mathrm{D}$ intake was included as a confounder, we assume that the associations mentioned are related to unfortified dairy products. Khan et al. ${ }^{(52)}$ followed up for about 12 years on a total of 41514 Australian men and women, aged 40-69 years at baseline. Overall there were about $10 \%$ incident fractures. A higher dietary $\mathrm{Ca}$ intake (adjusted for $\mathrm{Ca}$ intake from supplements) was associated with a lower fracture rate (hazard ratio (HR) 0.70; $95 \%$ CI 0.54, 0.92; P<0.004). Because milk products and dishes are the major source of $\mathrm{Ca}$ in the Australian diet (providing $42 \%$ of the dietary intake of $\mathrm{Ca}$ ), secondary analyses revealed that, compared with the reference quartile ( $<18$ dairy servings/week), a higher dairy product intake (quartile $4 ;>48$ servings/week) was associated with a decreased risk of fractures after 50 years of age (OR 0.78; $95 \%$ CI 0.62, 0.99).

A second large prospective study published by Michaëlsson et al. ${ }^{(3)}$ drew much attention. The mean Ca intake of women in this study was between $733 \mathrm{mg} / \mathrm{d}$ (mean $60 \mathrm{~g}$ milk/d; $37 \cdot 1 \% \mathrm{Ca}$ supplement users) and $1101 \mathrm{mg} / \mathrm{d}$ (mean $680 \mathrm{~g}$ milk/d; $23 \cdot 2 \%$ Ca supplement users), whereas the study of Khan et al. ${ }^{(52)}$ reported that the respective 5 th and 95 th percentiles of dietary 
Ca intake for women were 383 and $1555 \mathrm{mg} / \mathrm{d}$. For women who consumed three or more glasses of milk per d (mean $680 \mathrm{~g}$ ) as compared with less than one glass per d (mean $60 \mathrm{~g}$ ), Michaëlsson et al. ${ }^{(3)}$ found an HR for any fracture of $1.16(95 \%$ CI $1.08,1.25)$ and for hip fracture of 1.60 (95\% CI 1.39, 1.84). For every glass of milk in women no reduction in risk was observed with higher milk consumption for any fracture (HR 1.02; $95 \%$ CI 1.00, 1.04) or for hip fracture (HR 1.09; $95 \% \mathrm{CI}$ $1.05,1.13)$; the corresponding adjusted HR in men were 1.01 (95\% CI 0.99, 1.03) and 1.03 (95\% CI 0.99, 1.07). This negative effect was hypothetically explained by an effect of galactose, which in animal models may accelerate senescence due to an increase in oxidative stress and inflammation ${ }^{(53)}$. The study by Michaëlsson et al. ${ }^{(3)}$ used data from two large Swedish cohorts, one with 61433 women (39-74 years at baseline 1987-1990) and one with 45339 men (45-79 years at baseline 1997). The average follow-up was $20 \cdot 1$ years for women and 11.2 years for men ${ }^{(3)}$. The study included a larger number of subjects than the total number included in the meta-analyses of previous studies. Still this sample size and neither the sample sizes included in the meta-analyses reviewed in this paper might not be high enough according to Kanis et al.'s estimations ${ }^{(45)}$, which are based on a correlation between milk intake and BMD as outcome, and predict that in order to establish a significant association with fracture risk a sample size of at least 500000 subjects would be required.

\section{Conclusions on dairy products and bone health for adults}

In conclusion, based on one meta-analysis ${ }^{(42)}$ in primarily Caucasian women, increasing Ca intake from dairy sources with or without vitamin D increased BMD by 0.7 to $1.8 \%$ at the lumbar spine, total body, total hip or femoral neck at 2 years. This increase in BMD is less than one-fifth of the increase in BMD after pharmaceutical intervention ${ }^{(42)}$. However, as compared with the loss of BMD of about 1 to $2 \%$ during ageing ${ }^{(19)}$, it seems clinically relevant. For lumbar spine BMD, based on a few comparisons the increase seems to be independent of baseline dietary $\mathrm{Ca}$ intake. However, this could not be investigated for the other sites of BMD and therefore needs further study.

On the contrary, based on four systematic reviews ${ }^{(49)} /$ meta- $^{2}$ analyses $^{(43-45)}$ and two prospective studies ${ }^{(3,52)}$ with contrasting results, dairy products, either or not fortified with vitamin D, do not play a role or only to a small extent of about $5 \%$ in the reduction of hip fracture risk in a Caucasian population of mostly women. Based on pooled individual patient data, there are some indications that at very high age, osteoporotic fracture risk decreases with a higher milk intake.

\section{Dairy products $v$. calcium supplements}

For adults, one systematic review and meta-analysis is discussed that included RCT on BMD ${ }^{(42)}$. Using a random-effects model, two subgroups including the effects of dietary Ca sources $v$. Ca supplements were compared by a test for interaction between subgroups. For this purpose, seven studies on dietary sources of $\mathrm{Ca}$, of which six were on dairy products, were compared with thirty-four studies on Ca supplements. Three RCT overlap since they studied both forms of $\mathrm{Ca}$. The Ca dose of the trials on dietary sources and supplements was in 86 and $68 \%$ of cases $\geq 1000 \mathrm{mg} / \mathrm{d}$, and in 0 and $14 \% \leq 500 \mathrm{mg} / \mathrm{d}$, respectively. In all trials on dietary sources of $\mathrm{Ca}$, community-living participants were included, while in the trials on Ca supplements also participants living in institutions were included (12\%). Baseline Ca intake was $\leq 800 \mathrm{mg} / \mathrm{d}$ in 86 and $52 \%$ of the RCT on dietary sources or supplements, respectively. After 2 years of intervention, there was no difference in change of BMD at the lumbar spine, total hip and total body $(0 \cdot 7-1 \cdot 8 \% v \cdot 0 \cdot 8-1 \cdot 5 \%)$, except for BMD at the femoral neck and forearm. In the case of femoral neck BMD, this was in advantage of dietary sources of Ca, i.e. $1.8(95 \%$ CI $1.1,2 \cdot 6)$ v. $1.0(95 \%$ CI $0.5,1.4) \%$ ( $P$ interaction $=0 \cdot 05$ ). While for BMD at the forearm, the change was bigger due to the supplement intervention $(1.5 v \cdot 0 \cdot 1 \%$; $P$ interaction $=0 \cdot 01$ ). A closer look revealed that for the comparison of changes in BMD at the forearm and total body, only two RCT on dietary sources compared more than six RCT on supplements. For the other sites of BMD, a sufficiently high number of RCT of more than five trials on both forms were compared $^{(42)}$.

Since different studies were compared with different baseline $\mathrm{Ca}$ and dosages, the authors also did a pooled analyses of multiarm trials permitting a direct comparison of a Ca supplement arm with a dietary source of Ca arm. Out of seven multi-arm RCT, three trials ( $n$ 268) directly compared a dietary source of $\mathrm{Ca}$ arm (two comprising dairy sources) and a Ca supplement arm over 2 years' time. Baseline Ca intake was about $800 \mathrm{mg} / \mathrm{d}$ and comparable for the two different $\mathrm{Ca}$ interventions. In the trial on hydroxyapatite the dose of Ca was lower for the dietary source $(2500 \mathrm{mg} / \mathrm{d})$ than the supplement $(3320 \mathrm{mg} / \mathrm{d})$, while in the dairy product intervention trials $1000 \mathrm{mg} \mathrm{Ca} / \mathrm{d}$ in both interventions was given. Only for two bone sites, more than one RCT was included. For the lumbar spine three RCT (two comprising dairy sources) comparing dairy $\mathrm{Ca}$ /hydroxyapatite complex with supplements (not specified), the pooled analysis showed a non-significant BMD difference of $-0 \cdot 3$ ( $95 \% \mathrm{CI}-1 \cdot 3$, $0 \cdot 6) \%(P=0 \cdot 46)$. For the femoral neck, the pooled analysis also failed to show a significant BMD difference between dairy Ca and supplements (two RCT; 0.7 (95\% CI -1.3, 2.8)\%; $P=0.47$ ). According to these authors the similar effect due to increased intake of $\mathrm{Ca}$ through dietary sources or supplements suggests that the non-Ca components of the dietary sources of Ca do not directly affect $\mathrm{BMD}^{(42)}$.

In conclusion, based on one meta-analysis ${ }^{(42)}$ only when comparing different studies with a different background on baseline $\mathrm{Ca}$ intake, the femoral neck may seem to profit more from dietary sources than from supplements. Based on the meta-analysis of two to three RCT in adult participants that directly compared the efficacy of dairy products with Ca supplements; dairy products are not better for BMD than $\mathrm{Ca}$ supplements.

\section{Vitamin D-fortified $v$. -unfortified dairy products}

There is one meta-analysis on RCT that compared fortified with non-fortified dairy products on bone health. A subgroup analysis in the meta-analysis of Tai et al. ${ }^{(42)}$ showed no difference 
in effect of Ca monotherapy via dietary sources (eight RCT: BMD change $0.5(95 \% \mathrm{CI}-0.4,1.5) \%) v$. co-administered vitamin $\mathrm{D}$ (three RCT: BMD change $0.8(95 \%$ CI $0.2,1.4) \%)$ on BMD at the lumber spine after 1 year $(P=0 \cdot 62)$. For the other BMD sites or a longer intervention duration no comparison was possible. The daily dosages ranged between 300 and 800 IU (15 and 20 $\mu \mathrm{g}$ ) vitamin $\mathrm{D}$. The average baseline 25-hydroxyvitamin D (25(OH)D) levels was in all included RCT higher than $50 \mathrm{nmol} / \mathrm{l}$, thus sufficient, and therefore no additional effect of extra vitamin $D$ on bone can be expected. More studies, especially in participants with vitamin D insufficiency $(25(\mathrm{OH}) \mathrm{D}<50 \mathrm{nmol} / \mathrm{l})$, are needed to conclude whether vitamin D-fortified dairy products are better for bone mass than unfortified dairy products.

\section{Types of dairy products}

Most studies analysed were on milk. In prospective cohorts, the beneficial effects on BMD or hip fracture risk found for high $v$. low dairy product intake seem to be mediated mainly by milk and yogurt ${ }^{54,55)}$, which is probably related to their level of consumption. The definition of dairy product estimates consumed may differ in individual studies. The nutrient concentration on a weight basis is greater in yogurt and cheese than in milk, but serving sizes are typically less for these products than for milk ${ }^{(56)}$. We did not find RCT that compared comparable intakes of $\mathrm{Ca}$ and protein from different types of dairy products, which might be due to the fact that blinding of treatments is impossible. Since meta-analyses and individual RCT are lacking comparing different types of dairy products, we included prospective studies. Sahni et al. ${ }^{(54,55)}$ compared milk with other products made from milk in relation to bone health. In one study ${ }^{(54)}$ Sahni et al. followed 3724 adults aged 55 years (range 26-85 years) for 12 years. Exposure variables were quartiles or tertiles of milk, cheese, yogurt, cream (cream + sour cream + ice cream + cream cheese), fluid dairy product intake (milk + yogurt drinks), and total dairy product intake. In final models, simultaneously including dairy foods and therefore adjusting for each other, yogurt intake remained positively associated with trochanteric $\operatorname{BMD}(P=0 \cdot 04)$, while cream intake tended to be negatively associated with femoral neck BMD $(P=0.08)$. Milk and yogurt intake showed a positive but nonsignificant trend with femoral neck BMD $(P=0.06$ and 0.09 , respectively). No associations were observed for cheese intake or for lumbar spine BMD ${ }^{(54)}$. These data were extracted from the Framingham Offspring Study, which was performed in the USA and therefore includes mandatory fortification of milk with vitamin $D$. The same research group did a similar kind of study in older subjects $(n \text { 803) })^{(55)}$. The average age was 77 years (range 68-96 years). A total of ninety-seven hip fractures occurred over the mean follow-up time of 11.6 years. Participants with a medium milk intake ( $>1$ and $<7$ servings/week) or higher milk intake ( $\geq 7$ servings/week) tended to have lower hip fracture risk than those with low ( $\leq 1$ serving/week) intake (HR high $v$. low intake $0.58 ; 95 \%$ CI $0.31,1 \cdot 06 ; P=0.078$; and HR medium $v$. low intake: $0.61 ; 95 \%$ CI $0.36,1.08 ; P=0.071$ ). There appeared to be a threshold for milk, with a $40 \%$ lower risk of hip fracture among those with medium or high milk intake ( 7 servings/week) compared with those with low intake
( $P=0.061)$. Similarly, participants with a medium/high milk + yogurt intake ( $>1$ serving/week) appeared to have a20\% lower risk of hip fracture compared with those with low milk + yogurt intake ( $<1$ serving/week; $P=0 \cdot 104)$. These associations were further attenuated after adjustment for femoral neck BMD. No significant associations were seen for other dairy foods ( $P$ range $=0 \cdot 117-0 \cdot 746)$. Taken together, these results suggest that greater intakes of milk and milk + yogurt may lower risk for hip fracture in older adults through mechanisms that are partially, but not entirely, attributable to effects on $\mathrm{BMD}^{(55)}$.

\section{Dairy products $v$. other foods}

To be able to answer the question how dairy products compare with other foods in relation to bone health, we broadened our search strategy and included studies that address specific questions on the use of different protein or phosphate sources, or whether dairy product-free diets are appropriate enough to build strong bones. The systematic review and meta-analysis of observational studies in children at the ages of 2-13 years, primarily case-control in design (sixteen of eighteen), described by Händel et al. ${ }^{(34)}$, showed a higher upper and lower limb fracture risk with milk avoidance (based on six case-control studies), or with a higher intake of sugar-sweetened carbonated beverages (three studies) ${ }^{(34)}$. The latter is probably a 'replacement effect', as suggested by the data of Whiting ${ }^{(57)}$, showing that milk beverage intake in both boys and girls was inversely related to low nutrient-dense beverage consumption. In addition, girls, but not boys, have reduced bone mineral accrual when low nutrient-dense beverages replace milk beverages ${ }^{(57)}$.

Recently, 410 children aged 9-12 years were randomly assigned to one of six groups to receive $200 \mathrm{ml}$ of unfortified milk, fortified milk, unfortified orange juice, or fortified orange juice daily, or a supplement or placebo for 12 weeks. Plain milk supplied $240 \mathrm{mg} \mathrm{Ca} / \mathrm{d}$ and plain orange juice $180 \mathrm{mg} \mathrm{Ca} / \mathrm{d}$. Both fortified milk and fortified juice supplied $2.5 \mu \mathrm{g}$ vitamin D and $500 \mathrm{mg} \mathrm{Ca} / \mathrm{d}$. No significant difference was found in the changes of serum osteocalcin over time between plain milk and plain orange juice ( $27 v .13 \mu \mathrm{g} / \mathrm{l}$ ) or vitamin D- and Ca-fortified products $(30 v .24 \mu \mathrm{g} / 1)^{(58)}$. Osteocalcin serves as a bone formation marker, although serum carboxylated osteocalcin concentrations and, more strongly, the ratio of carboxylated:total osteocalcin, predict the occurrence of fractures in older community-dwelling adults much better than total osteocalcin ${ }^{(59)}$.

With regard to adults, one longer-term study on femoral neck and hip BMD ( 1.5 years) in Chinese postmenopausal women showed a higher impact of milk $v$. soya drinks. Both drinks supplied $250 \mathrm{mg}$ Ca daily. No effect was seen on the lumbar spine ${ }^{(60)}$. Various comparisons such as meat $v$. milk (same protein levels) or cola beverage $v$. milk or different $\mathrm{P}$ sources, among which meat and cheese (same P level; different Ca level) indicate a more beneficial effect of dairy products on markers of bone turnover and resorption in young adults ${ }^{(61-63)}$. These short-term dietary effects ( $24 \mathrm{~h}$ up to $10 \mathrm{~d}$ diet) of course need confirmation in long-term intervention studies with BMD as the outcome.

There are insufficient studies which mostly measure bone markers instead of BMD or BMC that allow for a good 
comparison between the effect of dairy products and other foods on bone health. The available data seem to indicate that dairy products may be more beneficial for building/maintaining bone mass than sugar-sweetened carbonated beverages or Ca-fortified soya drinks, which is probably related to the number of bone-relevant nutrients in the dairy package. There are gaps in our knowledge, however. We feel that some priority should be given to the (potential) replacement effect by sugarsweetened carbonated beverages in children.

\section{Discussion}

The role of dairy products either with or without vitamin D, for total-body BMC of Chinese and Caucasian children/adolescents with a low Ca intake, and for BMD of the total body, lumbar spine, total hip and femoral neck in mainly Chinese and Caucasian adult women has been sufficiently established. Recently, a review of the global Ca map revealed that there are many countries where Ca intake is very low, under $600 \mathrm{mg} /$ $\mathrm{d}^{(64)}$. Especially countries in Asia-Pacific region, South America and scattered throughout the Far East, and North Africa may be more likely to benefit from additional dairy products.

While no studies have been done on the association between dairy products and fracture risk in children/adolescents, many studies have been done on (older) adults. Tai et al. ${ }^{(42)}$ predicted a $1-2 \%$ increase in BMD to produce a $5-10 \%$ reduction in risk of fracture in adults, which is more than five times lower than observed with weak anti-resorptive agents. Therefore, a large sample size of about four to five times the sample sizes used in the meta-analyses or prospective studies described is needed to be able to study this relationship properly. There are two large Swedish studies on high intakes of milk (more than $600 \mathrm{ml} / \mathrm{d}$ ) and fracture risk. The oldest one showed a neutral association, while the more recent one showed a detrimental association in women but not men ${ }^{(3,48)}$. Given the northern latitude and small amount of vitamin D fortification in fat-reduced milk in Sweden, decreased vitamin D exposure may explain in part the influence of the Swedish study toward a neutral association between milk intake and hip fracture risk, as also pointed out by BischoffFerrari et al. ${ }^{(44)}$. In 116 women included in the cohort of the first executed Swedish study ${ }^{(48)}$, about $20 \%$ had $25(\mathrm{OH}) \mathrm{D}$ concentrations of less than $50 \mathrm{nmol} / 1$ during the winter of $2006^{(65)}$. In addition the level of milk consumption is much higher than the mean intake of adults in most countries, and it is worth noting that dietary questionnaires were performed in 1987-1990 and 1997, when milk in Sweden was fortified with a high dose of vitamin A; high levels of vitamin A have been linked to increased risk of fracture ${ }^{(66,67)}$. Although both studies adjusted for retinol intake by including it as a confounder, the question is whether this is valid. Vitamin A has a high variance ratio (ratio of intrasubject to intersubject variances) and therefore assessment of intake requires many days of dietary data ${ }^{(68)}$ and it is unclear to what extent this has been validated in the Swedish cohorts. In addition, older adults as included in both studies lose the capacity to clear high levels of ingested retinol ${ }^{(68)}$ and therefore intake might not reflect status. When leaving out one of the Swedish studies ${ }^{(48)}$ from a large well-controlled meta-analysis ${ }^{(44)}$, a marginally significant reduction of hip fracture risk of $5 \%$ per glass of milk/d was found in women. This was recently confirmed in a very large individual prospective study ${ }^{(69)}$, especially set up to compare with the results from the Swedish study ${ }^{(3)}$ and to address the relative lack of data in men. In this cohort 80600 women and 43306 men over 50 years of age were followed for up to 32 years. Per daily serving of milk, that was assessed every 4 years, a significant $8 \%$ lower risk of hip fracture was found in men and women combined (RR 0.92; $95 \%$ CI 0.87, 0.97) ${ }^{(69)}$. In addition, based on an individual patient data cohort, especially at an age older than 80 years, milk intake can reduce the risk on osteoporotic fractures (5-15\%). These percentages reductions confirm the estimations of Tai et al. ${ }^{(42)}$.

Vitamin D status is a well-known factor, important for bone health. Only the meta-analysis of Tai et al. ${ }^{(42)}$ compared vitamin D-fortified with unfortified dairy products. However, based on small short-term RCT they could not establish a higher BMD in the case of vitamin D fortification. All over the world, an adequate supply of both $\mathrm{Ca}$ and vitamin $\mathrm{D}$ is part of the nutritional recommendations to keep bone healthy. Appropriate levels of both dietary $\mathrm{Ca}$ and sufficient serum vitamin $\mathrm{D}$ levels are important for skeletal health ${ }^{(70)}$, which is confirmed by several meta-analyses ${ }^{(71,72)}$. However, by using standardised serum $25(\mathrm{OH}) \mathrm{D}$ data, vitamin D insufficiency $(25(\mathrm{OH}) \mathrm{D}<50 \mathrm{nmol} / \mathrm{l})$ in Europe and North America can be classified as a severe ( $>40 \%$ ) public health problem. Fortification of a wider range of foods is likely to have the potential to increase vitamin D intakes. For both a vitamin D-fortified, reduced-fat cheese and vitamin D-biofortified eggs a high efficacy has been shown ${ }^{(73,74)}$. The interactions between vitamin $\mathrm{D}$ and other micronutrients in dairy-based foods in relation to beneficial effects on bone further underscore the importance of dairy products as a vehicle for vitamin D fortification ${ }^{(75)}$.

Based on one meta-analysis ${ }^{(42)}$ directly comparing the efficacy of dairy products with Ca supplements, dairy products are not better for the BMD of adults than Ca supplements. However, Bischoff-Ferrari et al. ${ }^{(76)}$ in their meta-analysis pointed out that a balanced diet including dairy products containing several bone-essential nutrients might be of more importance with regard to building and maintaining BMD than Ca supplements. When pooling the RCT on Ca supplementation by tablets they found no reduction but an increase in hip fracture risk with $\mathrm{Ca}$; in a total of 6504 subjects, the pooled RR was 1.64 (95\% CI 1.02, $2 \cdot 64)$. Often Ca intake due to supplement use is considerably higher than the recommended daily allowances. Therefore from a safety perspective ${ }^{(76)}$ and reported effects on relationships with gastrointestinal symptoms and renal disease ${ }^{(71)}$, supplement use may be less preferable then dietary $\mathrm{Ca}$. In addition, increasing dietary $\mathrm{Ca}$ intake appears neutral with respect to cardiovascular effects, whereas Ca supplements might raise myocardial infarction risk $^{(77)}$. Furthermore, as only two in ten patients effectively comply with $\mathrm{Ca}+$ vitamin $\mathrm{D}$ prescription after 1 year or more ${ }^{(78)}$, obtaining bone-relevant nutrients from a balanced diet is in general preferred over the use of supplements.

The role of types of dairy products other than milk for bone mass and fracture risk reduction has so far obtained limited attention. Two epidemiological studies showed that yogurt is also associated with a lower risk for hip fracture in older 
adults $^{(54,55)}$. Based on nutrient composition and the portions consumed, it is to be expected that cheeses will also contribute to bone health ${ }^{(79)}$. A special feature of cheese is the presence of vitamin $\mathrm{K}_{2}^{(80)}$. Vitamin $\mathrm{K}$ serves as a cofactor for the microsomal $\gamma$-carboxylase which facilitates the post-translational conversion of glutamyl to $\boldsymbol{\gamma}$-carboxyglutamyl residues in osteocalcin and numerous other vitamin K-dependent proteins. In its $\gamma$-carboxylated state, osteocalcin is a Ca-binding protein in bone, thought to facilitate the mineralisation process ${ }^{(75)}$.

The overall trend in food consumption in Europe as well as in the USA is to drink less milk and more phosphoric acidcontaining soft drinks, which in turn results in a lower dietary Ca: $\mathrm{P}$ ratio. If a habitual diet lacks dairy products, the dietary Ca:P ratio will easily drop below the optimal desired level ${ }^{(81)}$, which from a bone-health perspective should range from $1: 1$ to $1 \cdot 5: 1 \mathrm{mg}$ Ca:mg $\mathrm{P}^{(82)}$. The short-term cola/meat or cheese studies ${ }^{(61-63)}$ showed higher serum parathyroid hormone and urinary Ca levels in the first quartile ( $\mathrm{Ca}: \mathrm{P}$ molar ratio $\leq 0.50) v$. the other quartiles (Ca:P molar ratio $>0 \cdot 50$ ), therefore underscoring benefits of dairy $v$. other food products that may decrease the $\mathrm{Ca}: \mathrm{P}$ ratio. In addition, dietary protein, which is absent in carbonated beverages, stimulates the osteotropic hormone insulin-like growth factor I (IGF-I), which is important for bone formation $^{(1)}$. Although in the past high protein intake was often assumed to exert a primarily detrimental impact on bone mass and skeletal health, the majority of studies indicate the opposite. A low-protein diet is associated with a higher risk of hip fractures, however, only under conditions of adequate Ca intake ${ }^{(83,84)}$.

\section{Research significance}

Current demographic trends leading to an increased number of individuals surviving past the age of 65 years will result in an increased number of osteoporotic fractures ${ }^{(85)}$. The number of hip fractures potentially can be reduced with dairy products via a beneficial effect on BMC/BMD, especially in the elderly. Drug therapy to reduce facture risk in the elderly is not always feasible but dietary modifications, specifically improving protein, $\mathrm{Ca}$, and vitamin D intakes, may be a more realistic option ${ }^{(86)}$. European guidance for the diagnosis and management of osteoporosis in postmenopausal women recommends a daily intake of at least $1000 \mathrm{mg} / \mathrm{d}$ for $\mathrm{Ca}, 800 \mathrm{IU} / \mathrm{d}(20 \mu \mathrm{g} / \mathrm{d})$ for vitamin $\mathrm{D}$ and $1 \mathrm{~g} / \mathrm{kg}$ body weight of protein for all women aged over 50 years ${ }^{(87)}$. However, there is still a high prevalence of Ca and vitamin D insufficiency in women aged $50+$ years. In addition, individuals need to consume an overall healthful diet, like increasing plant-based foods or dairy foods, to meet their nutrient requirements ${ }^{(88)}$. What strikes is that there are no permitted claims on individual foods or dietary patterns, although it is well known that some food categories, such as dairy products, provide a number of these bone-relevant nutrients in substantial amounts. The problems that investigators face when trying to establish firm proof for nutrition-related disorders of health have been aptly addressed by Heaney ${ }^{(89)}$ in his Atwater Memorial Lecture. Most nutrients act in all tissues, all tissues need many nutrients, and inadequate intake impairs many body systems. Nutrients work together, rather than in isolation, and often their effects will not develop when the intakes of other nutrients are suboptimal. Interdependencies among nutrients may well be a part of the explanation for the heterogeneity of results from different research centres and investigators. This 'orchestra function of nutrition' needs to be taken into account when addressing the role of dairy products for endpoints of (bone) health. Recent dietary approaches focusing on BMD from a food-group perspective also support the role of dairy products for healthy bones ${ }^{(90-92)}$.

\section{Conclusion}

Our review showed that (Ca from) dairy products with or without vitamin D positively influences bone mineralisation in children with a low baseline $\mathrm{Ca}$ intake, and also in adults. Whether this higher BMD in adults also depends on baseline $\mathrm{Ca}$ intake needs further study. Despite the results on BMC, there are currently no studies that have investigated the potential of dairy products to reduce fracture risk in children. In adults, a relatively small meta-analysis on pooled individual data ${ }^{(45)}$ and a very large meta-analysis ${ }^{(44)}$ showed that a daily intake of $200-250 \mathrm{ml}$ of milk is associated with a reduction in fracture risk of $5 \%$ or higher. Based on the meta-analyses of two to three RCT that directly compared the efficacy of dairy products with Ca supplements, dairy products are not better for BMD than $\mathrm{Ca}$ supplements. Most RCT compared vitamin D-fortified with unfortified dairy products in participants with a high vitamin D status, and therefore we cannot conclude whether vitamin D added to dairy products is more beneficial for bone health. However, several meta-analyses ${ }^{(71,72)}$ that showed that the combination of $\mathrm{Ca}$ and vitamin $\mathrm{D}$ is better than either of them alone underscore the importance of dairy products as a vehicle for vitamin D fortification. In general, further study on bone health is needed in other ethnicities than Chinese and Caucasians, and in men.

\section{Acknowledgements}

We would like to acknowledge Paul T. A. Lips, PhD, Professor Emeritus of VU University Medical Center, the Netherlands who evaluated this paper and provided advice.

The present review received no specific grant from any funding agency, commercial or not-for-profit sectors.

Both authors are employees at FrieslandCampina, a dairy company.

\section{References}

1. Heaney RP (2009) Dairy and bone health. J Am Coll Nutr 28, Suppl. 1, 82S-90S.

2. Feskanich D, Bischoff-Ferrari HA, Frazier AL, et al. (2014) Milk consumption during teenage years and risk of hip fractures in older adults. JAMA Pediatr 168, 54-60.

3. Michaëlsson K, Wolk A, Langenskiöld S, et al. (2014) Milk intake and risk of mortality and fractures in women and men: cohort studies. BMJ 349, g6015.

4. Heaney RP (2000) Calcium, dairy products and osteoporosis. J Am Coll Nutr 19, 83S-99S.

5. Zengin A, Prentice A \& Ward KA (2015) Ethnic differences in bone health. Front Endocrinol (Lausanne) 6, 24. 
6. Bonjour J-P, Kraenzlin M, Levasseur R, et al. (2013) Dairy in adulthood: from foods to nutrient interactions on bone and skeletal muscle health. J Am Coll Nutr 32, 251-263.

7. Weaver CM, Gordon CM, Janz KF, et al. (2016) The National Osteoporosis Foundation's position statement on peak bone mass development and lifestyle factors: a systematic review and implementation recommendations. Osteoporos Int 27, 1281-1386.

8. Rizzoli R, Bianchi ML, Garabédian M, et al. (2010) Maximizing bone mineral mass gain during growth for the prevention of fractures in the adolescents and the elderly. Bone 46, 294-305.

9. Rizzoli R (2008) Nutrition: its role in bone health. Best Pract Res Clin Endocrinol Metab 22, 813-829.

10. Esterle L, Jehan F, Sabatier J-P, et al. (2009) Higher milk requirements for bone mineral accrual in adolescent girls bearing specific Caucasian genotypes in the VDR promoter. J Bone Miner Res 24, 1389-1397.

11. Slemenda C, Christian J, Williams J, et al. (1991) Genetic determinants of bone mass in adult women: a reevaluation of the twin model and the potential importance of gene interaction on heritability estimates. J Bone Miner Res 6, 561-567.

12. Frost HM (1987) Bone "mass" and the "mechanostat": a proposal. Anat Rec 219, 1-9.

13. Weaver CM \& Heaney RP (editors) (2006) ) Calcium in Human Health (Nutrition and Health). Totawa. NJ: Humana Press.

14. Rizzoli R, Abraham C \& Brandi M-L (2014) Nutrition and bone health: turning knowledge and beliefs into healthy behaviour. Curr Med Res Opin 30, 131-141.

15. The Medical Research Library of Brooklyn (2014) A Guide to Research Methods: The Evidence Pyramid. SUNY Downstate Medical Center: Evidence Based Medicine Course. http://library. downstate.edu/EBM2/2100.htm (accessed February 2018).

16. Huncharek M, Muscat J \& Kupelnick B (2008) Impact of dairy products and dietary calcium on bone-mineral content in children: results of a meta-analysis. Bone 43, 312-321.

17. Heaney RP (2001) The bone remodeling transient: interpreting interventions involving bone-related nutrients. Nutr Rev 59, 327-334.

18. Matkovic V, Gael PK, Badenhop-Stevens NE, et al. (2005) Calcium supplementation and bone mineral density in females from childhood to young adulthood: a randomized controlled trial. Am J Clin Nutr 81, 175-188.

19. Lanham-New SA (2008) Importance of calcium, vitamin D and vitamin $\mathrm{K}$ for osteoporosis prevention and treatment. Proc Nutr Soc 67, 163-176.

20. Cadogan J, Eastell R, Jones N, et al. (1997) Milk intake and bone mineral acquisition in adolescent girls: randomised, controlled intervention trial. BMJ 315, 1255-1260.

21. Du X, Zhu K, Trube A, et al. (2004) School-milk intervention trial enhances growth and bone mineral accretion in Chinese girls aged 10-12 years in Beijing. Br J Nutr 92, 159-168.

22. Lau EMC, Lynn H, Chan YH, et al. (2004) Benefits of milk powder supplementation on bone accretion in Chinese children. Osteoporos Int 15, 654-658.

23. Ma DF, Zheng W, Ding M, et al. (2013) Milk intake increases bone mineral content through inhibiting bone resorption: metaanalysis of randomized controlled trials. e-SPENJ 8, e1-e7.

24. Volek JS, Gómez AL, Scheett TP, et al. (2003) Increasing fluid milk favorably affects bone mineral density responses to resistance training in adolescent boys. J Am Diet Assoc 103 $1353-1356$.

25. Tong R \& Zhang X (2004) The effect of fortified milk on growth and bone development in girls aged 10-12 y. In The Gth National Academic Conference of the Child and Adolescent Health Section of CPMA and the 3rd Academic Conference of the School Section of Chinese Health Education Association, Nanjing, China.
26. Liu JC, Zhang J \& Ouyang QH (2002) Effect of short-term milk drinking on bone mineral density in healthy girls during spurt growth period. Chinese J Clin Rehabil 6, 1618-1619.

27. Lanou AJ, Berkow SE \& Barnard ND (2005) Calcium, dairy products, and bone health in children and young adults: a reevaluation of the evidence. Pediatrics 115, 736-743.

28. Matkovic V, Fontana D, Tominac C, et al. (1990) Factors that influence peak bone mass formation: a study of calcium balance and the inheritance of bone mass in adolescent females. Am J Clin Nutr 52, 878-888.

29. Chan GM, Hoffman K \& McMurry M (1995) Effects of dairy products on bone and body composition in pubertal girls. J Pediatr 126, 551-556.

30. Dror DK \& Allen LH (2014) Dairy product intake in children and adolescents in developed countries: trends, nutritional contribution, and a review of association with health outcomes. Nutr Rev 72, 68-81.

31. Iuliano-Burns S, Wang X-F, Evans A, et al. (2006) Skeletal benefits from calcium supplementation are limited in children with calcium intakes near $800 \mathrm{mg}$ daily. Osteoporos Int 17, 1794-1800.

32. Bonjour J-P, Carrie A-L, Ferrari S, et al. (1997) Calciumenriched foods and bone mass growth in prepubertal girls calcium-enriched foods and bone mass growth in prepubertal girls: a randomized, double-blind, placebo-controlled trial. J Clin Invest 99, 1287-1294.

33. Merrilees MJ, Smart EJ, Gilchrist NL, et al. (2000) Effects of diary food supplements on bone mineral density in teenage girls. Eur J Nutr 39, 256-262.

34. Händel MN, Heitmann BL, Abrahamsen B, et al. (2015) Nutrient and food intakes in early life and risk of childhood fractures: a systematic review and meta-analysis. Am J Clin Nutr 102, 1182-1195.

35. Howland RH (2014) Early-life milk and late-life fracture. JAMA Pediatr 168, 683

36. Weaver CM (2014) Milk consumption and bone health. JAMA Pediatr 168, 12-13.

37. Heaney RP (2014) Early-life milk and late-life fracture. JAMA Pediatr 168, 682-683.

38. Feskanich D \& Willett WC (2014) In reply. JAMA Pediatr 168 , 683-684.

39. Welten DC, Kemper HCG, Post GB, et al. (1997) Longitudinal development and tracking of calcium and dairy intake from teenager to adult. Eur J Clin Nutr 51, 612-618.

40. Bailey DA, McKay HA, Mirwald RL, et al. (1999) A six-year longitudinal study of the relationship of physical activity to bone mineral accrual in growing children: The University of Saskatchewan Bone Mineral Accrual Study. J Bone Miner Res 14, 1672-1679.

41. Weinsier RL \& Krumdieck CL (2000) Dairy foods and bone health: examination of the evidence. Am J Clin Nutr 72, 681-689.

42. Tai V, Leung W, Grey A, et al. (2015) Calcium intake and bone mineral density: systematic review and meta-analysis. BMJ 351, h4183.

43. Xu L, McElduff P, D'Este C, et al. (2004) Does dietary calcium have a protective effect on bone fractures in women?A metaanalysis of observational studies. Br J Nutr 91, 625-634.

44. Bischoff-Ferrari H, Dawson-Hughes B, Baron J, et al. (2011) Milk intake and risk of hip fracture in men and women: a meta-analysis of prospective cohort studies.J Bone Miner Res 26, 833-839.

45. Kanis JA, Johansson H, Oden A, et al. (2005) A meta-analysis of milk intake and fracture risk: low utility for case finding. Osteoporos Int 16, 799-804.

46. Cumming RG, Cummings SR, Nevitt MC, et al. (1997) Calcium intake and fracture risk: results from the study of osteoporotic fractures. Am J Epidemiol 145, 926-934. 
47. Meyer HE, Pedersen JI, Løken EB, et al. (1997) Dietary factors and the incidence of hip fracture in middle-aged Norwegians. A prospective study. Am J Epidemiol 145, 117-123.

48. Michaëlsson K, Melhus H, Bellocco R, et al. (2003) Dietary calcium and vitamin $\mathrm{D}$ intake in relation to osteoporotic fracture risk. Bone 32, 694-703.

49. Bolland MJ, Leung W, Tai V, et al. (2015) Calcium intake and risk of fracture: systematic review. BMJ 351, h4580.

50. Lau EMC, Woo J, Lam V, et al. (2001) Milk supplementation of the diet of postmenopausal Chinese women on a low calcium intake retards bone loss. J Bone Miner Res 16, 1704-1709.

51. Munger RG, Cerhan JR \& Chiu BC (1999) Prospective study of dietary protein intake and risk of hip fracture in postmenopausal women. Am J Clin Nutr 69, 147-152.

52. Khan B, Nowson CA, Daly RM, et al. (2015) Higher dietary calcium intakes are associated with reduced risks of fractures, cardiovascular events, and mortality: a prospective cohort study of older men and women. J Bone Miner Res 30, 1758-1766.

53. Michaëlsson K, Wolk A, Melhus H, et al. (2017) Milk, fruit and vegetable, and total antioxidant intakes in relation to mortality rates: cohort studies in women and men. Am J Epidemiol 185, 345-361.

54. Sahni S, Tucker KL, Kiel DP, et al. (2013) Milk and yogurt consumption are linked with higher bone mineral density but not with hip fracture: the Framingham Offspring Study. Arch Osteoporos 8, 119.

55. Sahni S, Mangano KM, Tucker KL, et al. (2014) Protective association of milk intake on the risk of hip fracture: results from the Framingham Original Cohort. J Bone Miner Res 29, $1756-1762$.

56. Weaver CM (2014) How sound is the science behind the dietary recommendations for dairy? Am J Clin Nutr 99, 1217S-1222SS.

57. Whiting SJ, Healey A, Psiuk S, et al. (2001) Relationship between carbonated and other low nutrient dense beverages and bone mineral content of adolescents. Nutr Res 21, 1107-1115.

58. Neyestani TR, Hajifaraji M, Omidvar N, et al. (2014) Calciumvitamin D-fortified milk is as effective on circulating bone biomarkers as fortified juice and supplement but has less acceptance: a randomised controlled school-based trial. J Hum Nutr Diet 27, 606-616.

59. Luukinen H, Käkönen SM, Pettersson K, et al. (2000) Strong prediction of fractures among older adults by the ratio of carboxylated to total serum osteocalcin. J Bone Miner Res $\mathbf{1 5}$, $2473-2478$

60. Gui J-C, Brašić JR, Liu X-D, et al. (2012) Bone mineral density in postmenopausal Chinese women treated with calcium fortification in soymilk and cow's milk. Osteoporos Int $\mathbf{2 3}$, 1563-1570.

61. Budek AZ, Hoppe C, Michaelsen KF, et al. (2007) High intake of milk, but not meat, decreases bone turnover in prepubertal boys after 7 days. Eur J Clin Nutr 61, 957-962.

62. Karp HJ, Vaihia KP, Kärkkäinen MUM, et al. (2007) Acute effects of different phosphorus sources on calcium and bone metabolism in young women: a whole-foods approach. Calcif Tissue Int 80, 251-258.

63. Kristensen M, Jensen M, Kudsk J, et al. (2005) Short-term effects on bone turnover of replacing milk with cola beverages: a 10-day interventional study in young men. Osteoporos Int 16, 1803-1808.

64. Balk EM, Adam GP, Langberg VN, et al. (2017) Global dietary calcium intake among adults: a systematic review. Osteoporosis Int 28, 3315-3324.

65. Burgaz A, Åkesson A \& Annette O (2007) Associations of diet, supplement use, and ultraviolet $\mathrm{B}$ radiation exposure with vitamin D status in Swedish women during winter. Am J Clin Nutr 86, 1399-1404.
66. Rozenberg S, Body J-J, Bruyère O, et al. (2016) Effects of dairy products consumption on health: benefits and beliefs - a commentary from the Belgian Bone Club and the European Society for Clinical and Economic Aspects of Osteoporosis, Osteoarthritis and Musculoskeletal Diseases. Calcif Tissue Int 98, $1-17$.

67. Michaëlsson K, Lithell H, Vessby B, et al. (2003) Serum retinol levels and the risk of fracture. $N$ Engl J Med 348, 287-294.

68. Whiting S \& Lemke B (2009) Excess retinol intake may explain the high incidence of osteoporosis in Northern Europe. Nutr Rev 57, 192-196.

69. Feskanich D, Meyer HE, Fung TT, et al. (2018) Milk and other dairy foods and risk of hip fracture in men and women. Osteoporos Int 29, 385-396.

70. Carmeliet G, Dermauw V \& Bouillon R (2015) Vitamin D signaling in calcium and bone homeostasis: a delicate balance. Best Pract Res Clin Endocrinol Metab 29, 621-631.

71. Avenell A, Mak JCS \& O'Connell D (2014) Vitamin D and vitamin $\mathrm{D}$ analogues for preventing fractures in postmenopausal women and older men. Cochrane Database Syst Rev, issue 4, CD000227.

72. Lips P, Gielen E \& van Schoor NM (2014) Vitamin D supplements with or without calcium to prevent fractures. Bonekey Rep 3, 512.

73. Manios Y, Moschonis G, Mavrogianni C, et al. (2017) Reduced-fat Gouda-type cheese enriched with vitamin $\mathrm{D}_{3}$ effectively prevents vitamin $\mathrm{D}$ deficiency during winter months in postmenopausal women in Greece. Eur J Nutr 56, 2367-2377.

74. Hayes A, Duffy S, Grady MO, et al. (2016) Vitamin D-enhanced eggs are protective of wintertime serum 25hydroxyvitamin $\mathrm{D}$ in a randomized controlled trial of adults. Am J Clin Nutr 25, 629-637.

75. Cashman KD, van den Heuvel EG, Schoemaker RJ, et al. (2017) 25-Hydroxyvitamin D as a biomarker of vitamin D status and its modeling to inform strategies for prevention of vitamin D deficiency within the population. Adv Nutr 8, 947-957.

76. Bischoff-Ferrari HA, Dawson-Hughes B, Baron JA, et al. (2007) Calcium intake and hip fracture risk in men and women: a meta-analysis of prospective cohort studies and randomized controlled trials. Am J Clin Nutr 86, 1780-1790.

77. Li K, Kaaks R, Linseisen J, et al. (2012) Associations of dietary calcium intake and calcium supplementation with myocardial infarction and stroke risk and overall cardiovascular mortality in the Heidelberg cohort of the European Prospective Investigation into Cancer and Nutrition study (EPIC-Heidelberg). Heart 98, 920-925.

78. Castelo-Branco C, Cortés X \& Ferrer M (2010) Treatment persistence and compliance with a combination of calcium and vitamin D. Climacteric 13, 578-584.

79. Cheng S, Lyytikäinen A, Kröger H, et al. (2005) Effects of calcium, dairy product, and vitamin D supplementation on bone mass accrual and body composition in 10-12-y-old girls: a 2-y randomized trial. Am J Clin Nutr 82, 1115-1126; quiz, $1147-1148$

80. Beulens JWJ, van der ADL, Grobbee DE, et al. (2010) Dietary phylloquinone and menaquinones intakes and risk of type 2 diabetes. Diabetes Care 33, 1699-1705.

81. Kemi VE, Kärkkäinen MUM, Rita HJ, et al. (2010) Low calcium: phosphorus ratio in habitual diets affects serum parathyroid hormone concentration and calcium metabolism in healthy women with adequate calcium intake. BrJ Nutr 103, 561-568.

82. Calvo MS \& Tucker KL (2013) Is phosphorus intake that exceeds dietary requirements a risk factor in bone health? Ann N Y Acad Sci 1301, 29-35. 
83. Remer T, Krupp D \& Shi L (2014) Dietary protein's and dietary acid load's influence on bone health. Crit Rev Food Sci Nutr 54, 1140-1150.

84. Mangano KM, Sahni S \& Kerstetter JE (2014) Dietary protein is beneficial to bone health under conditions of adequate calcium intake: an update on clinical research. Curr Opin Clin Nutr Metab Care 17, 69-74.

85. Cauley JA (2013) Public health impact of osteoporosis. J Gerontol A Biol Sci Med Sci 68, 1243-1251.

86. Iuliano $S$ (2015) Nutrition: to supplement or not to supplement the elderly. In Nutrition and Bone Health, 231-247 [MF Holick and JW Nieves, editors]. New York: Springer.

87. Rizzoli R, Stevenson JC, Bauer JM, et al. (2014) The role of dietary protein and vitamin $\mathrm{D}$ in maintaining musculoskeletal health in postmenopausal women: a consensus statement from the European Society for Clinical and Economic Aspects of Osteoporosis and Osteoarthritis (ESCEO). Maturitas 79, $122-132$.

88. Cifelli CJ, Houchins JA, Demmer E, et al. (2016) Increasing plant based foods or dairy foods differentially affects nutrient intakes: dietary scenarios using NHANES 2007-2010. Nutrients 8, E422.
89. Heaney RP (2008) Nutrients, endpoints, and the problem of proof. J Nutr 138, 1591-1595.

90. Van den Hooven EH, Ambrosini GL, Huang R, et al. (2015) Identification of a dietary pattern prospectively associated with bone mass in Australian young adults. Am J Clin Nutr 102, 1035-1043.

91. de Jonge EAL, Kiefte-de Jong JC, de Groot LCPGM, et al. (2015) Development of a food group-based diet score and its association with bone mineral density in the elderly: The Rotterdam Study. Nutrients 7, 6974-6990.

92. Chen Y, Xiang J, Wang Z, et al. (2015) Associations of bone mineral density with lean mass, fat mass, and dietary patterns in postmenopausal Chinese women: a 2-year prospective study. PLOS ONE 10, e0137097.

93. Petridou E, Karpathios T, Dessypris N, et al. (1997) The role of dairy products and non alcoholic beverages in bone fractures among schoolage children. Scand J Soc Med $\mathbf{2 5}$, 119-125.

94. Wyshak G \& Frisch RE (1994) Carbonated beverages, dietary calcium, the dietary calcium/phosphorus ratio, and bone fractures in girls and boys. J Adolesc Health 15, 210-215. 